\title{
AGE AND GENDER FEATURES OF DEPRESSIVE AND ANXIETY SYMPTOMATICS OF DEPRESSIVE DISORDERS
}

DOI: $10.36740 /$ WLek202007130

\author{
Oleksandr O. Belov, Nataliya G. Pshuk \\ NATIONAL PIROGOV MEMORIAL MEDICAL UNIVERSITY, VINNYTSIA, UKRAINE
}

\begin{abstract}
The aim: of the study is to study the features of the clinical phenomenology of depressive disorders at the present stage, taking into account gender and age factors. Materials and methods: Clinically examined 107 men and 138 women with bipolar affective disorder (current episode of depression), depressive episode and recurrent depressive disorder using HDRS, HARS, BDI, C. Spilberger's Scale of Reactive and Personality Anxiety.

Results: In all patients showed an increase in the severity of depression and anxiety with age, but in women the greatest differences were found between the middle and older age groups, and in men when comparing young and middle age groups. In young patients the level of agitated depression is higher for men, and women showed the higher overall level of anxiety, somatic anxiety, undifferentiated depression, reactive and personality anxiety. In patients aged 30-44, men have a significantly higher overall score of HARS depression, the level of adynamic, agitated and undifferentiated depression, the level of depression on BDI. In the older age group, the levels of depression in men and women are not significantly different, and the levels of mental anxiety and personality anxiety in women are significantly higher.

Conclusions: The general tendency consisting in increasing the severity of depression with age, and more pronounced indicators of depression in men, and anxiety in women. In men, the greatest increase in the severity of depression occurs before the age of 44 years, and in women after 45 years.
\end{abstract}

KEY WORDS: depressive disorders, depressive and anxious phenomenology

Wiad Lek. 2020;73(7):1476-1479

\section{INTRODUCTION}

The problem of depression is one of the main problems of modern psychiatric science and practice; depressive disorders are associated with suicidal behavior, reduced of quality of life, and social disadaptation both in patients with depressions and in their microsocial environment [13]. According to modern studies, depressive disorders are characterized by polymorphism of symptoms, difficulty of diagnosis and resistance to therapy [4-7]. In this regard, it is important to study the clinical phenomenology of depressive disorders at the present stage, which can be the basis for the development of effective preventive measures [8-10].

\section{THE AIM}

The aim of the study is to study the features of the clinical phenomenology of depressive disorders at the present stage, taking into account gender and age factors.

\section{MATERIALS AND METHODS}

With the observance of the principles of biomedical ethics, we have clinically examined 107 men and 138 women who applied for medical care at Vinnitsa Regional Psycho-Neurological Hospital from 2015 to 2019. The nosological structure of the contingent was as follows: bipolar affective disorder, the current episode of depression (ICD10 codes F31.3, F31.4): 42 men (39.8\% of the total number of men surveyed) and 38 women $(27.5 \%$ of the total the number of women); depressive episode (F32.0, F32.1, F32.2): 32 men (29.9\%) and 64 women (46.4\%), recurrent depressive disorder (F33.0, F33.1, F33.2): 33 men (30.8\%) and 36 women $(26.1 \%)$, respectively.

The average age of the men was $34.2 \pm 11.1$ years, and $33.2 \pm 11.4$ years for women $(\mathrm{p}=0.422)$, the average duration of depression was $5.7 \pm 5.8$ years for men, and $4.5 \pm 5.4$ years for women $(p=0.064)$.

3 subgroups were allocated in group of men and women depending on the age of patients at the time of the study: up to 30 years (M1 and W1, respectively), from 33 to 44 years (M2 and W2 groups, respectively), 45 years and older (M3 and W3 groups, respectively).

The study was conducted using M. Hamilton's Depression [11] and Anxiety Scale [12] (HDRS and HARS), A. Beck's Depression Invertory (BDI) [13], C. Spilberger's Scale of Reactive and Personality Anxiety in Y. Khanin modification [14].

Statistical analysis of differences between groups was carried out using non-parametric Mann-Whitney test.

\section{RESULTS AND DISCUSSION}

The results of the analysis of depressive and anxious manifestations in men are given in table I.

The main trend is an increase in the severity of depressive and anxious symptoms with age. This naturally reflects the 
Table I. Features of depressive and anxious manifestations in men, taking into account age factor

\begin{tabular}{|c|c|c|c|c|c|c|}
\hline \multirow[b]{2}{*}{ Indicators } & \multicolumn{3}{|c|}{ Clinical groups } & \multicolumn{3}{|c|}{$\begin{array}{c}\text { level of statistical significance of } \\
\text { differences (p) }\end{array}$} \\
\hline & $\begin{array}{c}M 1 \\
M \pm m / M e \\
\left(Q_{25}-Q_{75}\right)\end{array}$ & $\begin{array}{c}M 2 \\
M \pm m / M e \\
\left(Q_{25}-Q_{75}\right)\end{array}$ & $\begin{array}{c}M 3 \\
M \pm m / M e \\
\left(Q_{25}-Q_{75}\right)\end{array}$ & M1 vs M2 & M1 vs M3 & M2 vs M3 \\
\hline \multicolumn{7}{|c|}{ M. Hamilton's Depression Scale (HDRS) } \\
\hline Total score & $\begin{array}{c}15,8 \pm 5,8 / 13,5 \\
(12,0-19,0)\end{array}$ & $\begin{array}{c}22,3 \pm 9,1 / 21,0 \\
(13,0-31,0)\end{array}$ & $\begin{array}{c}28,7 \pm 11,1 / 33,0 \\
(14,0-38,0)\end{array}$ & 0,002 & 0,000 & 0,010 \\
\hline Adynamic depression & $\begin{array}{c}11,8 \pm 4,7 / 10,0 \\
(8,0-14,0)\end{array}$ & $\begin{array}{c}16,0 \pm 6,6 / 16,0 \\
(10,0-23,0)\end{array}$ & $\begin{array}{c}21,2 \pm 7,1 / 24,0 \\
(11,0-26,0)\end{array}$ & 0,003 & 0,000 & 0,003 \\
\hline Agitation depression & $\begin{array}{c}6,8 \pm 3,3 / 6,0 \\
(4,0-10,0)\end{array}$ & $\begin{array}{c}9,7 \pm 4,7 / 10,0 \\
(6,0-14,0)\end{array}$ & $\begin{array}{c}12,2 \pm 6,3 / 14,0 \\
(4,0-17,0)\end{array}$ & 0,005 & 0,003 & 0,052 \\
\hline Depression with fear & $\begin{array}{l}5,7 \pm 4,4 / 4,0 \\
(3,0-9,0)\end{array}$ & $\begin{array}{c}8,5 \pm 5,1 / 8,0 \\
(3,0-13,0)\end{array}$ & $\begin{array}{l}12,4 \pm 5,9 / 15,0 \\
(5,0-17,0)\end{array}$ & 0,014 & 0,000 & 0,005 \\
\hline $\begin{array}{l}\text { Undifferentiated } \\
\text { depression }\end{array}$ & $\begin{array}{c}3,0 \pm 2,0 / 2,5 \\
(2,0-3,0)\end{array}$ & $\begin{array}{c}5,4 \pm 2,5 / 5,5 \\
(3,0-8,0)\end{array}$ & $\begin{array}{c}6,0 \pm 3,0 / 7,0 \\
(2,0-8,0)\end{array}$ & 0,000 & 0,001 & 0,288 \\
\hline \multicolumn{7}{|c|}{ M. Hamilton's Anxiety Scale (HARS) } \\
\hline Total score & $\begin{array}{c}10,3 \pm 5,28,5 \\
(7,0-11,0)\end{array}$ & $\begin{array}{l}15,4 \pm 7,2 / 14,0 \\
(10,0-22,0)\end{array}$ & $\begin{array}{c}21,9 \pm 11,2 / 26,0 \\
(8,0-33,0)\end{array}$ & 0,001 & 0,001 & 0,018 \\
\hline Psychical anxiety & $\begin{array}{c}8,3 \pm 2,5 / 8,0 \\
(7,0-9,0)\end{array}$ & $\begin{array}{c}10,2 \pm 3,4 / 9,5 \\
(7,0-13,0)\end{array}$ & $\begin{array}{c}11,9 \pm 4,6 / 14,0 \\
(7,0-16,0)\end{array}$ & 0,011 & 0,006 & 0,130 \\
\hline Somatic anxiety & $\begin{array}{l}2,1 \pm 3,0 / 1,0 \\
(0,0-3,0)\end{array}$ & $\begin{array}{c}5,2 \pm 4,3 / 5,0 \\
(2,0-8,0)\end{array}$ & $\begin{array}{l}10,0 \pm 7,1 / 11,0 \\
(1,0-16,0)\end{array}$ & 0,000 & 0,000 & 0,011 \\
\hline \multicolumn{7}{|c|}{ A. Beck's Depression Invertory (BDI) } \\
\hline Total score & $\begin{array}{c}25,1 \pm 13,3 / 23,0 \\
(15,0-34,0)\end{array}$ & $\begin{array}{c}36,1 \pm 17,2 / 37,0 \\
(19,0-53,0)\end{array}$ & $\begin{array}{c}48,8 \pm 17,9 / 59,0 \\
(26,0-62,0)\end{array}$ & 0,003 & 0,000 & 0,003 \\
\hline $\begin{array}{c}\text { Cognitive-affective } \\
\text { subscale }\end{array}$ & $\begin{array}{c}16,2 \pm 9,1 / 13,0 \\
(10,0-24,0)\end{array}$ & $\begin{array}{c}23,3 \pm 11,4 / 24,5 \\
(12,0-34,0)\end{array}$ & $\begin{array}{c}30,2 \pm 11,7 / 37,0 \\
(13,0-39,0)\end{array}$ & 0,006 & 0,000 & 0,007 \\
\hline $\begin{array}{c}\text { Subscale of } \\
\text { somatic depressive } \\
\text { manifestations }\end{array}$ & $\begin{array}{c}8,8 \pm 4,9 / 9,0 \\
(5,012,0)\end{array}$ & $\begin{array}{c}12,7 \pm 6,5 / 12,0 \\
(7,0-19,0)\end{array}$ & $\begin{array}{c}18,7 \pm 6,5 / 21,0 \\
(13,0-23,0)\end{array}$ & 0,007 & 0,000 & 0,001 \\
\hline \multicolumn{7}{|c|}{ C. Spilberger's Scale of Reactive and Personality Anxiety } \\
\hline Reactive anxiety & $\begin{array}{c}32,0 \pm 7,9 / 29,5 \\
(26,032,0)\end{array}$ & $\begin{array}{c}40,4 \pm 10,3 / 42,0 \\
(32,0-49,0)\end{array}$ & $\begin{array}{c}48,2 \pm 14,5 / 55,0 \\
(29,0-62,0)\end{array}$ & 0,000 & 0,000 & 0,014 \\
\hline Personality anxiety & $\begin{array}{c}36,3 \pm 7,9 / 34,0 \\
(30,040,0)\end{array}$ & $\begin{array}{c}42,2 \pm 9,6 / 43,0 \\
(33,0-51,0)\end{array}$ & $\begin{array}{l}38,7 \pm 11,2 / 33,0 \\
(31,0-47,0)\end{array}$ & 0,006 & 0,754 & 0,129 \\
\hline
\end{tabular}

progression of the pathological process in time. However, the most pronounced differences in men were found when comparing groups up to 30 years and 30-44 years, while differences between groups of 30-44 years and 45 years and older are less pronounced.

For women, there are other patterns (Table II). They also showed an increase in the severity of depression and anxiety with age, but the greatest differences were found between the middle and older age groups. So, although the rates of depression in the middle age group are greater than in the young one, these differences are not statistically significant. Significant differences were found only for anxiety indicators (a general indicator for HARS, an indicator of somatic anxiety and an indicator of reactive anxiety). At the same time, in the older age group, all indicators are significantly more than in the middle.

Statistically significant differences between men and women were identified mainly in patients aged 30-44 (Table III).
In young patients under the age of 30 years the level of agitated depression is higher for men, and for women, the overall level of anxiety, the level of somatic anxiety and the level of reactive anxiety are higher. Also, women showed higher levels of undifferentiated depression and personality anxiety, but the level of statistical significance for these indicators is somewhat less. In patients aged 30-44, men have a significantly higher overall score of HARS depression, the level of adynamic and agitated depression and undifferentiated depression, the level of depression on BDI, including the cognitive-affective subscale and subscale of somatic manifestations of depression. In the older age group ( 45 years and more), the levels of depression in men and women are not significantly different, and the levels of mental anxiety and personality anxiety in women are significantly higher.

The study revealed some trends of depressive and anxious manifestations of depressive disorders in different age groups. 
Table II. Features of depressive and anxious manifestations in women, taking into account age factor

\begin{tabular}{|c|c|c|c|c|c|c|}
\hline \multirow[b]{2}{*}{ Indicators } & \multicolumn{3}{|c|}{ Clinical groups } & \multicolumn{3}{|c|}{$\begin{array}{l}\text { level of statistical significance of } \\
\text { differences (p) }\end{array}$} \\
\hline & $\begin{array}{c}W 1 \\
M \pm m / M e \\
\left(Q_{25}-Q_{75}\right) \\
\end{array}$ & $\begin{array}{c}W 2 \\
M \pm m / M e \\
\left(Q_{25}-Q_{75}\right)\end{array}$ & $\begin{array}{c}W 3 \\
M \pm m / M e \\
\left(Q_{25}-Q_{75}\right) \\
\end{array}$ & W1 vs W2 & W1 vs W3 & W2 vs W3 \\
\hline \multicolumn{7}{|c|}{ M. Hamilton's Depression Scale (HDRS) } \\
\hline Total score & $\begin{array}{c}14,6 \pm 6,1 / 12,0 \\
(11,0-17,0)\end{array}$ & $\begin{array}{l}18,0 \pm 9,0 / 14,0 \\
(12,0-27,0)\end{array}$ & $\begin{array}{l}28,1 \pm 10,3 / 31,0 \\
\quad(19,0-37,0)\end{array}$ & 0,076 & 0,000 & 0,000 \\
\hline Adynamic depression & $\begin{array}{c}10,8 \pm 4,6 / 9,0 \\
(8,0-12,0)\end{array}$ & $\begin{array}{c}12,9 \pm 6,7 / 10,0 \\
(8,0-20,0)\end{array}$ & $\begin{array}{c}20,1 \pm 6,8 / 22,0 \\
(15,0-26,0)\end{array}$ & 0,189 & 0,000 & 0,000 \\
\hline Agitation depression & $\begin{array}{c}5,7 \pm 3,6 / 4,0 \\
(3,0-8,0)\end{array}$ & $\begin{array}{c}7,3 \pm 5,0 / 6,0 \\
(3,0-12,0)\end{array}$ & $\begin{array}{l}12,6 \pm 5,4 / 13,0 \\
(8,0-17,0)\end{array}$ & 0,119 & 0,000 & 0,000 \\
\hline Depression with fear & $\begin{array}{c}6,5 \pm 4,0 / 5,0 \\
(4,0-9,0)\end{array}$ & $\begin{array}{c}7,7 \pm 5,7 / 5,0 \\
(3,0-14,0)\end{array}$ & $\begin{array}{c}12,6 \pm 5,6 / 14,0 \\
(11,0-17,0)\end{array}$ & 0,693 & 0,000 & 0,001 \\
\hline $\begin{array}{l}\text { Undifferentiated } \\
\text { depression }\end{array}$ & $\begin{array}{c}3,5 \pm 1,9 / 3,0 \\
(2,0-4,0)\end{array}$ & $\begin{array}{c}4,4 \pm 2,6 / 3,0 \\
(2,0-7,0) \\
\end{array}$ & $\begin{array}{c}6,4 \pm 2,8 / 8,0 \\
(5,0-8,0)\end{array}$ & 0,318 & 0,000 & 0,002 \\
\hline \multicolumn{7}{|c|}{ M. Hamilton's Anxiety Scale (HARS) } \\
\hline Total score & $\begin{array}{c}13,2 \pm 5,5 / 12,0 \\
(9,0-17,0)\end{array}$ & $\begin{array}{c}16,7 \pm 7,9 / 14,0 \\
(11,0-23,0)\end{array}$ & $\begin{array}{c}25,9 \pm 11,2 / 26,5 \\
(15,0-36,0)\end{array}$ & 0,023 & 0,000 & 0,000 \\
\hline Psychical anxiety & $\begin{array}{c}9,5 \pm 4,0 / 8,0 \\
(6,0-13,0)\end{array}$ & $\begin{array}{c}10,8 \pm 4,4 / 10,0 \\
(7,0-15,0)\end{array}$ & $\begin{array}{c}15,0 \pm 5,8 / 15,5 \\
(10,0-20,0)\end{array}$ & 0,074 & 0,000 & 0,001 \\
\hline Somatic anxiety & $\begin{array}{c}3,8 \pm 2,5 / 4,0 \\
(2,0-5,0)\end{array}$ & $\begin{array}{c}5,8 \pm 4,0 / 5,0 \\
(3,0-8,0) \\
\end{array}$ & $\begin{array}{c}10,8 \pm 6,2 / 12,5 \\
(6,0-16,0)\end{array}$ & 0,004 & 0,000 & 0,000 \\
\hline \multicolumn{7}{|c|}{ A. Beck's Depression Invertory (BDI) } \\
\hline Total score & $\begin{array}{c}21,8 \pm 13,5 / 19,0 \\
(11,0-31,0)\end{array}$ & $\begin{array}{c}27,6 \pm 17,7 / 24,0 \\
(14,0-45,0)\end{array}$ & $\begin{array}{c}46,3 \pm 17,5 / 50,5 \\
(35,0-61,0)\end{array}$ & 0,151 & 0,000 & 0,000 \\
\hline $\begin{array}{c}\text { Cognitive-affective } \\
\text { subscale }\end{array}$ & $\begin{array}{c}14,2 \pm 8,9 / 12,0 \\
(6,0-21,0)\end{array}$ & $\begin{array}{c}17,6 \pm 11,5 / 16,0 \\
(7,0-28,0)\end{array}$ & $\begin{array}{c}28,9 \pm 12,3 / 32,5 \\
(19,0-39,0)\end{array}$ & 0,202 & 0,000 & 0,000 \\
\hline $\begin{array}{c}\text { Subscale of } \\
\text { somatic depressive } \\
\text { manifestations }\end{array}$ & $\begin{array}{c}7,6 \pm 5,1 / 7,0 \\
(3,0-11,0)\end{array}$ & $\begin{array}{c}10,0 \pm 6,9 / 9,0 \\
(4,0-15,0)\end{array}$ & $\begin{array}{c}17,3 \pm 5,8 / 19,0 \\
(13,0-22,0)\end{array}$ & 0,104 & 0,000 & 0,000 \\
\hline \multicolumn{7}{|c|}{ C. Spilberger's Scale of Reactive and Personality Anxiety } \\
\hline Reactive anxiety & $\begin{array}{c}37,0 \pm 8,5 / 33,0 \\
(31,0-44,0)\end{array}$ & $\begin{array}{c}42,5 \pm 10,4 / 42,0 \\
(33,0-50,0)\end{array}$ & $\begin{array}{c}53,0 \pm 14,0 / 54,5 \\
(42,0-65,0)\end{array}$ & 0,007 & 0,000 & 0,000 \\
\hline Personality anxiety & $\begin{array}{c}40,2 \pm 9,9 / 39,0 \\
(31,0-44,0)\end{array}$ & $\begin{array}{c}40,3 \pm 8,5 / 41,0 \\
(33,0-44,0)\end{array}$ & $\begin{array}{c}49,7 \pm 10,9 / 54,0 \\
(42,0-58,0)\end{array}$ & 0,725 & 0,000 & 0,000 \\
\hline
\end{tabular}

It has been established that, in general, men have higher rates of depression than women. This may be due to the fact that men seek psychiatric help later, and in more severe cases than women because of the stereotype that exists in society that a man must be enduring and endure difficulties. Perhaps men are also more affected by stigmatization. In women, higher levels of anxiety were revealed, which can be considered as one of the manifestations of gender pathomorphosis of depression.

It has been established that, in general, the severity of depressive and anxious manifestations in depressive disorders increases with age. However, in men and women, the trends are different: in men, a more pronounced deterioration was observed before the age 44 years, and in women - after 45 years. These features require further deeper study of the dynamics and pathomorphosis of depressive disorders, taking into account gender and age factors.

\section{CONCLUSIONS}

The study of the features of depressive and anxious manifestations of depressive disorders revealed its main tendencies, consisting in increasing the severity of depression with age, and more pronounced indicators of depression in men, and anxiety in women. In men, the greatest increase in the severity of depression occurs before the age of 44 years, and in women after 45 years.

\section{REFERENCES}

1. Zuckerman H., Pan Z., Park C. et al. Recognition and Treatment of Cognitive Dysfunction in Major Depressive Disorder. Frontiers in Psychiatry, 2018; 9: 655.

2. Pshuk N.G., Stukan L.V., Kaminska A.0. Introducing system of psychotherapeutic intervention for family caregivers of patients with endogenous mental disorders. Wiadomosci Lekarskie, 2018; 71(5): 980-985. 
Table III. The levels of statistical significance of differences when comparing men and women

\begin{tabular}{|c|c|c|c|}
\hline \multirow{2}{*}{ Indicators } & \multicolumn{3}{|c|}{ Level of statistical significance (p) } \\
\hline & M1 vs W1 & M2 vs W2 & M3 vs W3 \\
\hline Total score on HDRS & 0,137 & 0,012 & 0,744 \\
\hline Adynamic depression subscale of HDRS & 0,197 & 0,015 & 0,376 \\
\hline Agitation depression subscale of HDRS & 0,047 & 0,016 & 0,851 \\
\hline Depression with fear subscale of HDRS & 0,154 & 0,394 & 0,954 \\
\hline Undifferentiated depression subscale of HDRS & 0,061 & 0,048 & 0,519 \\
\hline Total score on HARS & 0,001 & 0,435 & 0,213 \\
\hline Psychical anxiety on HARS & 0,371 & 0,627 & 0,033 \\
\hline Somatic anxiety on HARS & 0,000 & 0,367 & 0,702 \\
\hline Total score on BDI & 0,222 & 0,015 & 0,479 \\
\hline Cognitive-affective subscale of BDI & 0,248 & 0,014 & 0,788 \\
\hline Subscale of somatic depressive manifestations of BDI & 0,185 & 0,040 & 0,324 \\
\hline Reactive anxiety on C. Spilberger's Scale & 0,001 & 0,399 & 0,278 \\
\hline Personality anxiety on C. Spilberger's Scale & 0,080 & 0,351 & 0,001 \\
\hline
\end{tabular}

3. Ogbo F.A., Mathsyaraja S., Koti R.K., Perz J., Page A. The burden of depressive disorders in South Asia, 1990-2016: findings from the global burden of disease study. BMC Psychiatry, 2018; 18: 333.

4. McLachlan G. Treatment resistant depression: what are the options? BMJ, 2018; 363: k5354.

5. Wiles N., Taylor A., Turner N. et al. Management of treatment-resistant depression in primary care: a mixed-methods study. British Journal of General Practice. 2018; 68(675): e673-e681.

6. Limandri B.J., Treatment-Resistant Depression: Identification and Treatment Strategies. Journal of Psychosocial Nursing and Mental Health Services. 2018; 56(9): 11-15.

7. Rakhman L.V., Markova M.V. Clinical and therapeutic levels of pathomorphosis of treatment-resistant depression. Medical Psychology, 2014; 1: 36-40.

8. Parker G., McCraw S., Paterson A. Clinical features distinguishing grief from depressive episodes: A qualitative analysis. Journal of Affective Disorders, 2015; 1(176): 43-47.

9. Kraus C., Kadriu B., Lanzenberger R., Zarate C.A., Kasper S. Prognosis and improved outcomes in major depression: a review. Translational Psychiatry, 2019; 9: 127.

10. Kautzky A., Dold M., Bartova L. et al. Clinical factors predicting treatment resistant depression: affirmative results from the European multicenter study. Acta Psychiatrica Scandinavica, 2018; 139: 78-88.

11. Hamilton M. A rating scale for depression by Max Hamilton. Journal of Neurology, Neurosurgery, Psychiatry, 1960; 23: 56-62.

12. Hamilton M. The assessment of anxiety states by rating. British Journal of Medical Psychology, 1959; 32: 50-55.

13. Beck A.T., Ward C.H., Mendelson M., Mock J., Erbaugh J. An inventory for measuring depression. Archives of General Psychiatry, 1961; 4: 561-571.
The work is done within complex theme "Mental disadaptation (clinical phenomenology, formation mechanisms, complex correction (state registration number 0115U004000))》 department of medical psychology and psychiatry National Pirogov Memorial Medical University (Vinnytsya, Ukraine).

\section{ORCID and contributionship:}

Oleksandr O. Belov: 0000-0002-0156-0777 A,B,C,D,E

Nataliya G. Pshuk: 0000-0001-9857-2565 E,F

\section{Conflict of interest:}

The Authors declare no conflict of interest.

\section{CORRESPONDING AUTHOR Oleksandr 0. Belov \\ National Pirogov Memorial Medical University \\ 109 Pirogova st., 21100 Vinnytsya, Ukraine \\ tel: +380678636827 \\ e-mail: oleksbelov@gmail.com}

Received: 04.07.2019

Accepted: 10.04 .2020

A - Work concept and design, B - Data collection and analysis, C - Responsibility for statistical analysis, D - Writing the article, $\mathbf{E}$ - Critical review, $\mathbf{F}$ - Final approval of the article 